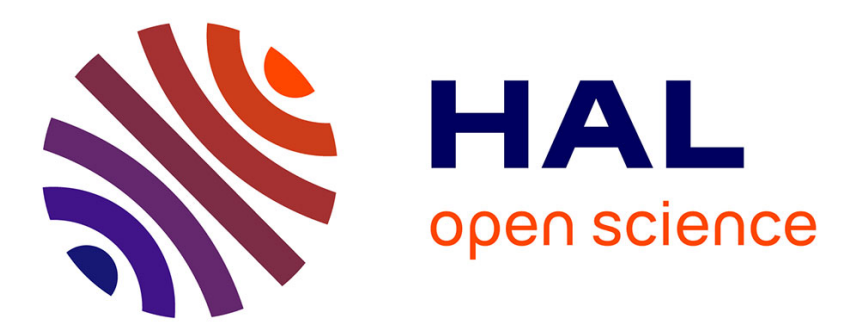

\title{
Synthesis and Biodistribution of 1-[2-(cyclopentadienyltricarbonyltechnetium-99m)-2- oxo-ethoxy-phenyl]-1,2-di- (p-hydroxyphenyl)but-1-ene for tumor imaging
}

Tesnim Dallagi, Mouldi Saidi, Gérard Jaouen, Siden Top

\section{To cite this version:}

Tesnim Dallagi, Mouldi Saidi, Gérard Jaouen, Siden Top. Synthesis and Biodistribution of 1[2-(cyclopentadienyltricarbonyltechnetium-99m)-2- oxo-ethoxy-phenyl]-1,2-di- (p-hydroxyphenyl)but1-ene for tumor imaging. Journal of Organometallic Chemistry, 2019, 591, pp.1-6. 10.1016/j.jorganchem.2019.04.006 . hal-02163476

\section{HAL Id: hal-02163476 \\ https://hal.sorbonne-universite.fr/hal-02163476}

Submitted on 24 Jun 2019

HAL is a multi-disciplinary open access archive for the deposit and dissemination of scientific research documents, whether they are published or not. The documents may come from teaching and research institutions in France or abroad, or from public or private research centers.
L'archive ouverte pluridisciplinaire HAL, est destinée au dépôt et à la diffusion de documents scientifiques de niveau recherche, publiés ou non, émanant des établissements d'enseignement et de recherche français ou étrangers, des laboratoires publics ou privés. 


\title{
Synthesis and Biodistribution of 1-[2-(cyclopentadienyltricarbonyltechnetium-99m)-2- oxo-ethoxy-phenyl]-1,2-di- (p-hydroxyphenyl)but-1-ene for tumor imaging
}

\author{
Tesnim Dallagi, ${ }^{\text {a }}$ Mouldi Saidi, ${ }^{a}$ Gérard Jaouen, ${ }^{\text {b,c }}$ Siden Top ${ }^{c^{*}}$
}

a) Laboratoire de biotechnologies et technologies nucléaires. Centre National des Sciences et Technologies Nucléaires. Technopôle de Sidi Thabet. 2020 Sidi Thabet Tunisie

b) PSL, Chimie ParisTech, 11 rue Pierre et Marie Curie, F-75005 Paris, France

c) Sorbonne Université, UPMC Univ Paris 6, UMR 8232 CNRS, IPCM, place Jussieu, F75005 Paris, France

\section{Correspondence:}

* Dr. Tesnim Dallagi

e-mail: tesnim.dallegi@gmail.com

* Dr Siden Top

e-mail: siden.top@upmc.fr

\begin{abstract}
The high incidence and mortality of breast cancer and other estrogen receptor related tumors motivates efforts to develop innovative imaging probes to effectively diagnose, evaluate the extent of the tumor, and predict the efficacy of treatments while concurrently and selectively delivering anticancer agents to the cancer tissues. In the present study, 1-[2(cyclopentadienyltricarbonyltechnetium-99m)-2-oxo-ethoxy-phenyl]-1,2-di-(phydroxyphenyl)but-1-ene was prepared and investigated as a potential agent for imaging estrogen receptors (ERs) in associated tumors. The compound was obtained in high


radiochemical purity and radiochemical yields. The biodistribution of the radioactive compound in mature female rats showed an ER-mediation in the ovarian target tissues as the uptake was reduced by a blocking dose of estradiol. The nonspecific uptake in muscle was relatively low.

Keywords: Estrogen receptor, ${ }^{99 \mathrm{~m}} \mathrm{Tc}$ radiolabelling, SPECT, tumor imaging, biodistribution, tumor.

\section{Introduction}

Some types of tumors are traditionally classified according to their hormone receptor status: Hormone-dependent tumors (Hormone receptor positive), and hormone-independent tumors (Hormone receptors negative). In the case of breast tumors, this designation comes from the fact that hormone-dependent cancer cells, whose proliferation is induced by estrogen, exhibit an accumulation of a specific intracellular receptor protein: the alpha form of the estrogen receptor $(\mathrm{ER} \alpha)$. An adjuvant treatment with anti-estrogens or with aromatase inhibitors is used for patients with hormone-dependent breast cancer. These receptors serve as targets for endocrine therapies of these cancers [1-4]. Knowledge of the receptor status can lead to more effective individualized treatment. But the receptors can also be used as targets for diagnostic imaging and radiotherapy. Diagnostic imaging can be achieved by administration of a suitably radiolabeled ligand that accumulates in the receptor-positive tumor cells where it can be detected and quantified by imaging. Such images can sometimes be used to predict whether hormone therapy might be effective or not [5-8]. Therefore, the development of such hormone receptor ligands for diagnostic imaging is a promising area of research. 
Nuclear medicine imaging modalities, using specific targeting moieties, play a crucial role in the diagnosis, staging, and follow-up for patients with cancer. Radiotracer-based imaging approaches, such as single-photon emission computed tomography (SPECT) and positron emission tomography (PET) could provide a non-invasive in vivo assessment providing information about tumor localization and progression [9]. Several radionuclides are used in nuclear medicine, including iodine-131, indium-111, thallium-201, fluorine-18, technetium$99 \mathrm{~m}$, gallium-67 and others [10]. Technetium-99m $\left({ }^{99 \mathrm{~m}} \mathrm{Tc}\right)$ is one of the most common radiotracers for imaging. This isotope has suitable physical and chemical characteristics, including a physical half-life of $6.02 \mathrm{~h}$ and gamma emission of low energy (140 keV) with the added advantage of abundant availability in nuclear medicine laboratories and low cost [1113]. An interesting compound containing both ${ }^{99 \mathrm{~m}} \mathrm{Tc}$ and Pt, Pt-LQ-Tc ( LQ = mono((4-(3(bis(quinolin-2-ylmethyl)amino)propylcarbamoyl)pyridinium-1-yl), has been designed in order to combine therapeutics and diagnosis in the same molecule [14].

Diagnostic imaging of breast by positron emission tomography (PET) is well established [15] and has been achieved using steroids labeled with fluorine-18 such as $16 \alpha-$ $\left[{ }^{18} \mathrm{~F}\right]$ fluoroestradiol (FES) [16]. Although a number of steroids labeled with bromine, fluorine and iodine radioisotopes have been prepared and studied [17-25], especially in terms of their potential for selective radiotherapy, their use in imaging studies, particularly in humans, has been more limited. While most of these agents were based on steroidal estrogens, a few investigations were focused on nonsteroidal estrogens or antiestrogens including selective ER modulators (SERMs) [3].

In 1996, Jaouen and coworkers coupled ferrocene to the biovector hydroxytamoxifen to create a new class of compounds, called ferrocifens [26]. These compounds were initially designed to combine the antiestrogenic properties of tamoxifen with a potential cytotoxic effect of ferrocene to possibly obtain new therapeutic advantages [27-28]. In an effort to 
develop this class of compounds, 1-(2-ferrocenyl-2-oxoethoxyphenyl)-1,2-bis-(4hydroxyphenyl)but-1-ene, 1, was synthesized (Chart 1) [29]. This type of ferrocenyl compound is suitable for use as a precursor in the synthesis of the technetium analog, 2 (Chart 1), by performing an organometallic exchange reaction developed for steroids by Wenzel [30] and Katzenellenbogen [31-32].

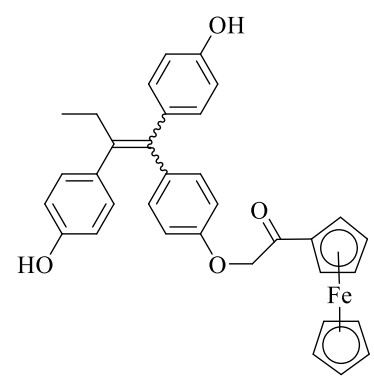

1

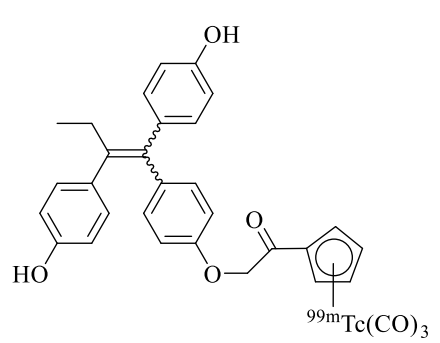

2

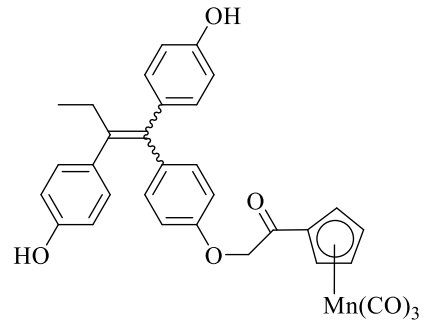

3

Chart 1. Ferrocenyl, manganese and ${ }^{99 \mathrm{~m}} \mathrm{Tc}$ derivatives.

In 2001, Alberto found an efficient method to generate aqua-ion $\left[{ }^{99 \mathrm{~m}} \mathrm{Tc}(\mathrm{CO})_{3}\left(\mathrm{H}_{2} \mathrm{O}\right)_{3}\right]^{+}[33]$. He demonstrated later that the cyclopentadienyltricarbonyltechnetium compound could be conveniently prepared from a reaction between $\left[{ }^{99 \mathrm{~m}} \mathrm{Tc}(\mathrm{CO})_{3}\left(\mathrm{H}_{2} \mathrm{O}\right)_{3}\right]^{+}$and cyclopentadienide derivatives [34-36]. 2 was first obtained from the reaction of $\mathbf{1}$ with $\left[{ }^{99 \mathrm{~m}} \mathrm{Tc}(\mathrm{CO})_{3}\left(\mathrm{H}_{2} \mathrm{O}\right)_{3}\right]^{+}$in DMSO/water at $120^{\circ} \mathrm{C}$ [37]. The best yield obtained for 2 was $70 \%$, which is slightly too low to allow the use of this approach for biodistribution study. We have now found good conditions for the double ligand transfer reaction involving $\mathbf{1},\left[{ }^{99} \mathrm{TcO}_{4}\right]^{-}$and $\mathrm{Mn}(\mathrm{CO})_{5} \mathrm{Br}$ to produce 2 in $95 \%$ yield. For identification of the technetium compound, a manganese or rhenium analog was used for comparison using the HPLC technique [38-39]. Therefore, 1-[4(2-(cyclopentadienyltricarbonylmanganese)-2-oxo-ethoxy)phenyl]-1,2-di(p-hydroxyphenyl)but-1-ene, $\mathbf{3}$, was also prepared [40]. In the present study, we report the synthesis of $\mathbf{2}$ and the determination of in vitro radiochemical stability. In addition, blood circulation time was evaluated. A biodistribution study was also performed to demonstrate the feasibility of using $\mathbf{2}$ as a potential agent for imaging estrogen receptors (ERs) in breast tumor. 


\section{Experimental}

The synthesis of the ferrocenyl complex, 1 [29] and the cyclopentadienyltricarbonylmanganese derivative, 3 [39] have been previously published.

2.1. 1-[2-(cyclopentadienyltricarbonyltechnetium-99)-2-oxo-ethoxy-phenyl]-1.2-di-(phydroxyphenyl)but-1-ene, 2

$1(1 \mathrm{mg})$ and $\mathrm{Mn}(\mathrm{CO})_{5} \mathrm{Br}(1 \mathrm{mg})$ were dissolved in $150 \mu \mathrm{L}$ of dimethylformamide in a $10 \mathrm{~mL}$ glass tube and $150 \mu \mathrm{L}\left[{ }^{99 \mathrm{~m}} \mathrm{TcO}_{4}\right]^{-}$in saline was added. The vial was sealed and purged with nitrogen for $10 \mathrm{~min}$ and heated in an oil bath at $150{ }^{\circ} \mathrm{C}$ for $1 \mathrm{~h}$. The mixture was purified by chromatography on a silica gel plate (TLC) (diethyl ether/petroleum ether 8/2) to give 2 . Radio-TLC (diethyl ether) gave a peak with an $\mathrm{Rf}=0.8$ (yield $90 \%$ ). HPLC retention time $=$ $22.73 \mathrm{~min}$. The solution was purified from ${ }^{99 \mathrm{~m}} \mathrm{TcO}_{2}$ using a $0.22 \mathrm{~mm}$ syringe filter, as previously described by Fernandes et al [41].

\subsection{Biological pH stability study.}

Purified $2(100 \mu \mathrm{L} .60 \mu \mathrm{Ci})$ was added to potassium phosphate buffer $(900 \mathrm{~mL}, 0.1 \mathrm{M})$ at $\mathrm{pH}$ 7.4. The vial was sealed and incubated at $37.0^{\circ} \mathrm{C}$ for the duration of study. The solution was examined by radio-HPLC at $30 \mathrm{~min} .1 \mathrm{~h}, 2 \mathrm{~h}, 3 \mathrm{~h}$ and $24 \mathrm{~h}$ during incubation to determine the effective stability of the compound.

\subsection{In vitro stability study.}

An in vitro stability study was carried out in isolated heparinized whole rat blood (mature female Wistar rats). The whole blood ( $5 \mathrm{~mL}$ ) was incubated with $100 \mu \mathrm{Ci}$ of 2 in $100 \mu \mathrm{L}$ ethanol for $30 \mathrm{~min}, 1 \mathrm{~h}, 2 \mathrm{~h}, 3 \mathrm{~h}$ and $24 \mathrm{~h}$ at $37.0^{\circ} \mathrm{C}$. A sample of blood $(1 \mathrm{~mL})$ was taken from the solution each time. The sample was centrifuged at $5000 \mathrm{rpm}$ for $5 \mathrm{~min}$ to separate plasma and cellular fractions and individual fractions were counted in a well counter. The plasma was then treated with $\mathrm{CH}_{3} \mathrm{CN}(1 \mathrm{~mL})$ and centrifuged as before and the supernatant was separated 
from the precipitated debris. The fractions were again counted with the bulk of activity residing in the plasma supernatant. The radioactive species in the supernatant were analysed by radio-HPLC.

\subsection{Kinetic study}

The kinetic study was carried out according to the relevant national regulation using mature (5-6 weeks old) female Wistar rats weighing between 180 and 200 g. Purified 2 was dissolved in $15 \%$ ethanol/saline buffer and injected via the tail vein. The dose employed was $80 \mu \mathrm{Ci}$ per animal (in $300 \mathrm{~mL}$ volume). At the specified time points post-injection of 2 , blood samples were collected by heart puncture. The injected dose (ID) was calculated by comparison with dose standards prepared from the injected solution at appropriate counting rates. The data were expressed as percentage of ID per gram of tissue (\% ID/g of blood). The biological halflife of compound 2 was determined using the following formula:

$T_{b}=T_{p} \times T_{\text {eff }} / T_{p}-T_{\text {eff }} ; T_{\text {eff }}=0.693 / K_{e} ; K_{e}=\log \left(C_{1} / C_{2}\right) / t_{2}-t_{1} ; K_{e}=$ elimination constant determined from curve.

\subsection{In vivo biodistribution.}

The biodistribution studies were carried out according to the relevant national regulation using mature (5-6 weeks old) female Wistar rats weighing between 180 and 200 g. Purified 2 was dissolved in $15 \%$ ethanol/saline buffer and injected via the tail vein under slight ether anesthesia. The dose employed was $80 \mu \mathrm{Ci}$ per animal (in $300 \mathrm{~mL}$ volume). and one set of animals was co-injected with radiotracer together with a blocking dose (15 mg) of estradiol.

At the specified time points post-injection of 2, groups of three animals each were sacrificed by heart puncture; tissues of interest were removed and weighed; and radioactivity was counted. The injected dose (ID) was calculated by comparison with dose standards prepared from the injected solution at appropriate counting rates. The data were expressed as percentage of ID per gram of tissue (\% ID/g of tissue). For each animal group, the data were 
averaged and standard deviation was calculated. Data were analysed by multifactorial analysis of variance (ANOVA. SPSS 12.0 for Windows) and significant differences among treatments were considered using Student's t test at the $\mathrm{P}<0.05$ level.

\section{Results and discussion}

\subsection{Synthesis}

Intensive development of nuclear medicine in the field of cancer diagnosis and therapy is currently taking place. The most important diagnostic and therapeutic radiopharmaceuticals, which selectively distribute within given tissues or organs, are formed by coordination compounds with a diagnostic or therapeutic radiometal firmly attached to a selected biologically active molecule. Among diagnostic radionuclides technetium-99m $\left(\mathrm{T}_{1 / 2}\right.$ $=6 \mathrm{~h}, \mathrm{E \gamma}=140 \mathrm{keV}$ ) is most commonly used for SPECT applications due to its favorable physical properties, ready availability from the ${ }^{99} \mathrm{Mo}^{-99 \mathrm{~m}} \mathrm{Tc}$ generator and relatively low cost $[42]$.

The synthesis of the ferrocenyl derivative 1 was published in the literature [29]. The $\mathrm{IC}_{50}$ values of $11.3 \mu \mathrm{M}$ and $7.8 \mu \mathrm{M}$ were found respectively against hormone-dependent breast cancer cells (MCF-7) and against prostate cancer cells PC3. Its relative binding affinity (RBA) value for the alpha form of the estrogen receptor is $14 \%$.

Cyclopentadienyltricarbonylmanganese compound $\mathbf{3}$ was prepared according to the literature procedure [40].

Scheme 1 shows the synthesis of cyclopentadienyltricarbonyltechnetium compound 2 . 


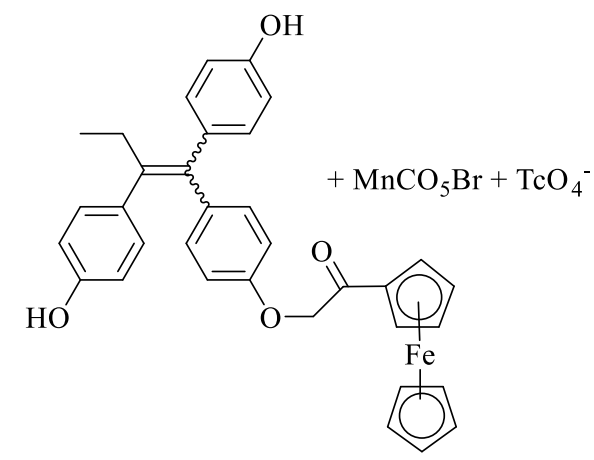

1

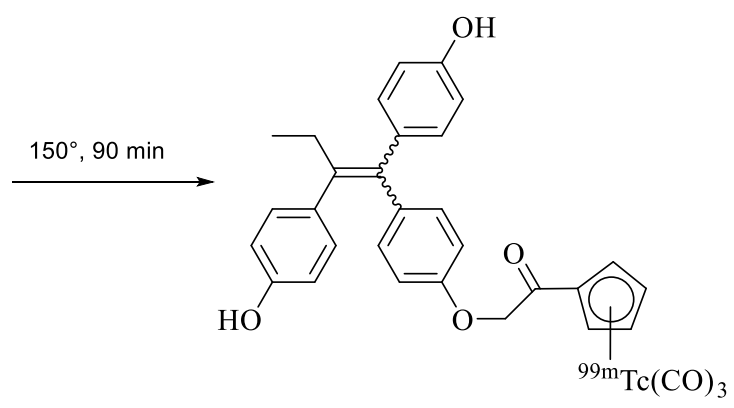

2

Scheme 1. synthesis of cyclopentadienyltricarbonyltechnetium compound 2

Heating the mixture of 1 with $\left[{ }^{99 \mathrm{~m}} \mathrm{TcO}_{4}\right]^{-}$and $\mathrm{Mn}(\mathrm{CO})_{5} \mathrm{Br}$ in dimethylformamide in a sealed tube at $150^{\circ} \mathrm{C}$ for 90 min resulted in formation of technetium compound 2 in $95 \%$ yield after purification by TLC chromatography. 


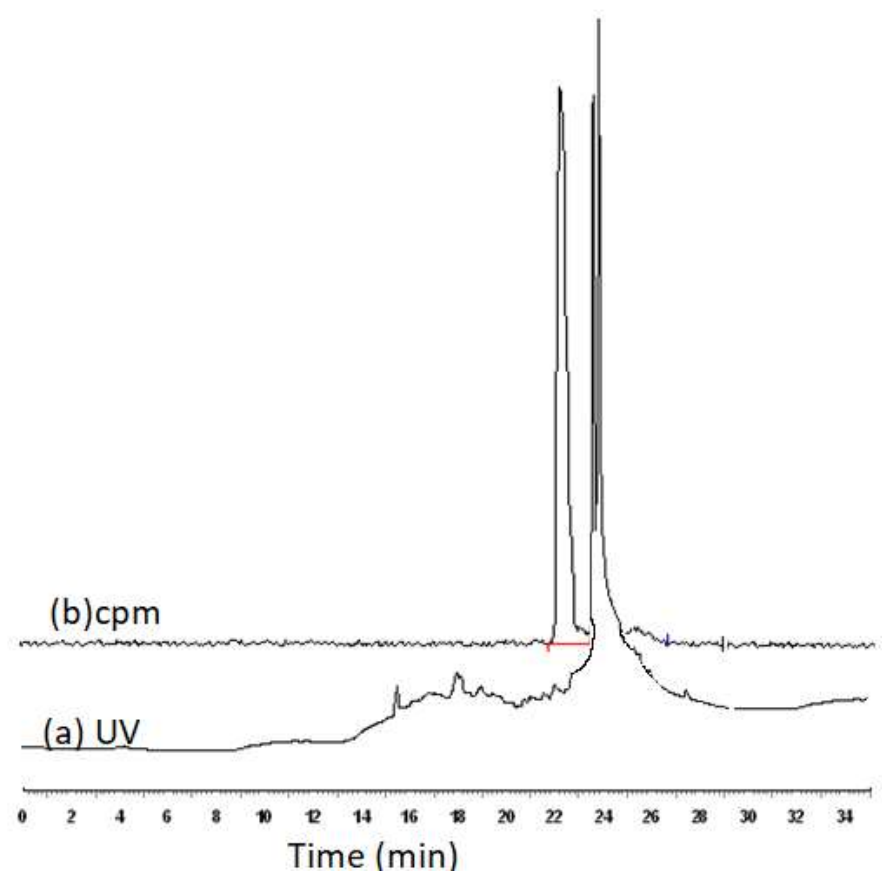

Figure 1. (a) UV-HPLC (254 nm) chromatogram of 3 and (b) Radio-HPLC chromatogram of 2.

The technetium compound, 2, was identified by comparison of its retention time to that of manganese analog 3 (Figure 1).

The radiolabeling protocol to obtain compound $\mathbf{2}$ was successfully optimized to achieve high yields. According to the American Pharmacopoeia [43], radiopharmaceutical preparations are suitable for in vivo administration if their radioactive impurities do not exceed $10 \%$. Use of the optimized protocol described in this study resulted in the detection of

\subsection{Biochemical studies}

The in vitro stability study was carried out in isolated whole rat blood following the procedure reported in the literature [39-40, 44]. Around $93 \%$ of the radioactivity was separated into supernatant from the pellet over the period of $3 \mathrm{~h}$, indicating little binding to cells or cellular proteins in the blood. According to the radio-HPLC analysis of the supernatant. 2 was the only radioactive species observed during $30 \mathrm{~min}$ of incubation. Compound 2 was also incubated with a potassium phosphate buffer at $37^{\circ} \mathrm{C}$ for $22 \mathrm{~h}$; the same stability results were found (figure 2). 


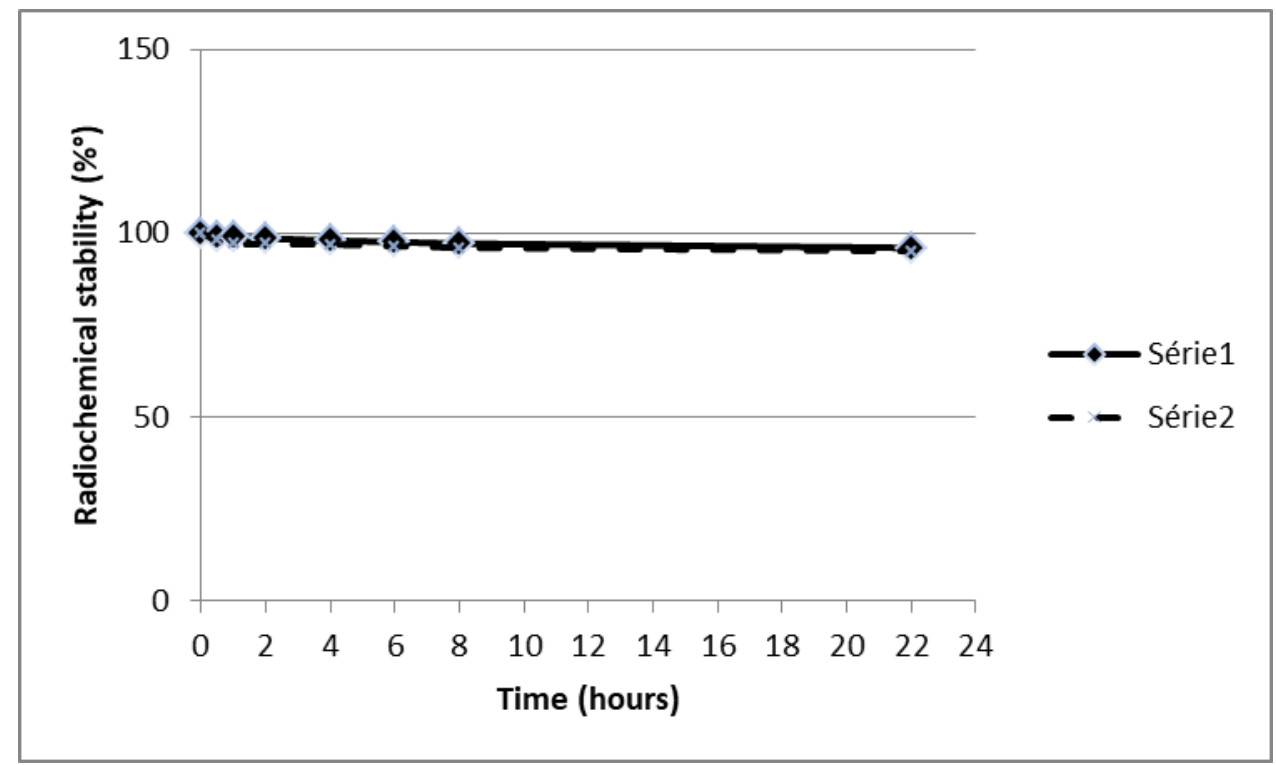

Figure 2. In vitro stability of $\mathbf{2}$ as a function of time in the presence of saline solution (Series 1), at room temperature, or rat plasma (Series 2), at $37^{\circ} \mathrm{C}$.

Radiolabeling stability is a mandatory characteristic for radiopharmaceutical platforms. In the event that metal detachment occurs, biodistribution and images will no longer be reliable and may lead to wrong interpretations [36-37]. 2 showed high stability in vitro (over 95\%) throughout the experiment (Figure 2).

The kinetic study was undertaken on female Wistar rats. A solution of purified 2 in $15 \%$ ethanol/saline buffer was injected via the tail vein. Blood samples were collected by heart puncture at $30 \mathrm{~min}, 1 \mathrm{~h}, 2 \mathrm{~h}, 3 \mathrm{~h}$ et $24 \mathrm{~h}$ post injection for concentration determination. Figure 3 shows that the plasma activity increased significantly during first 30 min before a fast decrease within $5 \mathrm{~h}$. After that time, a slow decrease was observed until $20 \mathrm{~h}$. Using this last curve section for the half-live determination, a value of $14.68 \mathrm{~h}$ was found for the half-life of 2 . 


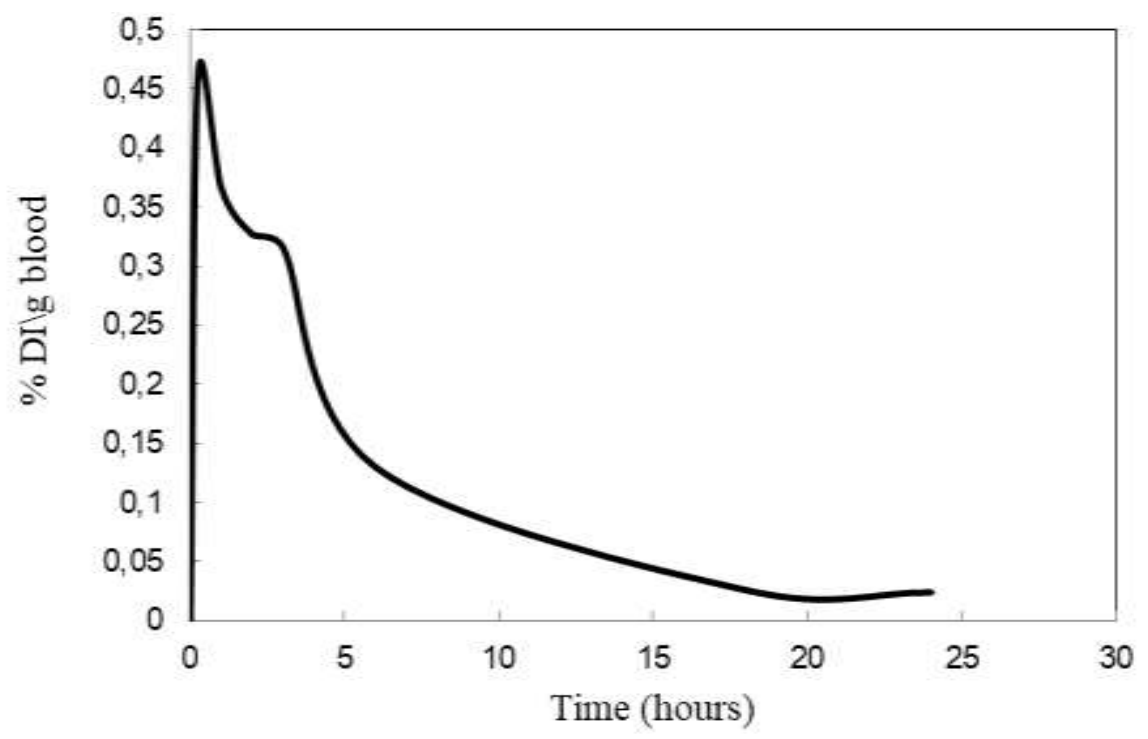

Figure 3 . In vivo disappearance of compound 2 in mature female rats.

Comparing to the cyclopentadienyltricarbonyltechnetium-99m 4 (Chart 2), published before in literature [39], 2 is more stable (14.68 h versus $5.52 \mathrm{~h}$ )

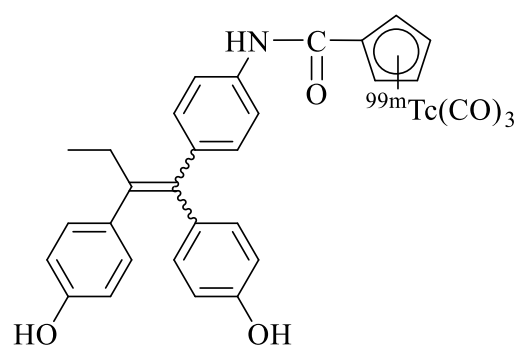

4

Chart 2 Cyclopentadienyltricarbonyltechnetium-99m 4

Long circulation time is an important feature for radiopharmaceuticals since a large number of passages through the targeted areas might favor radiotracer accumulation leading to better target/non-target ratios. For imaging purposes, a stability of compound with a halflife ranging from 4 to $6 \mathrm{~h}$ is suitable to achieve a reasonable signal-to-noise ratio [12].

A biodistribution study was thus performed to demonstrate the feasibility of $\mathbf{2}$ as a 
radiotracer for breast cancer. Purified 2 was reconstituted in 15\% ethanol-saline and injected into mature female Wistar rats (180 to $200 \mathrm{~g}$ ) via the tail vein. The dose of $\mathbf{2}$ employed was 80 $\mu \mathrm{Ci} /$ animal. Animals were sacrificed at $15 \mathrm{~min}, 1 \mathrm{~h}, 2 \mathrm{~h}, 3 \mathrm{~h}, 6 \mathrm{~h}, 18 \mathrm{~h}$ and $24 \mathrm{~h}$ post-injection. Table 1 shows the uptake of $\mathbf{2}$ in selected tissues of rats. The uptake values were calculated as a percent injected dose per gram of tissue (\% ID/g).

\section{Table 1}

At 15 min post injection, the uptake by uterus is similar to ovaries and in the same range as for muscle and bone. Interestingly, the ovaries/muscle and uterus/muscle ratios are $2.01 \pm 0.01$ and $2 \pm 0.02$, respectively, thus opening the possibility of imaging of these organs.

At $2 \mathrm{~h}$ post-injection point, there is an uptake by ovaries with $0.66 \pm 0.07 \% \mathrm{ID} / \mathrm{g}$. Apart from the high uptake by the liver and lung $(9.87 \pm 1.68$ and $21.86 \pm 1.70 \% \quad \mathrm{ID} / \mathrm{g}$, respectively), the uptake of kidney, spleen and heart is higher than that of ovaries. The ovaries/muscle and ovaries/blood ratios are 6.11 and 1.94 respectively. At 6 h post-injection, uptake in the ovaries was reduced to $0.183 \pm 0.015 \% \mathrm{ID} / \mathrm{g}$; while up to $75 \%$ of the radioactivity in liver and lung was washed out. At $24 \mathrm{~h}$ post injection, all tissue activities were reduced with highest activity in the liver. We note that the biodistribution shows a significant uptake in the liver, lung and spleen due to the importance of these routes for excretion. 
Table 2. Tissue biodistribution of $\mathbf{2}$ in mature female rats: blocking study.

\begin{tabular}{lcc}
\hline & \multicolumn{2}{c}{ Percent injected dose/gram \pm S.D. $(\mathrm{n}=3)$} \\
\cline { 2 - 3 } blood & $2 \mathrm{~h}$ & $2 \mathrm{~h}$ (Block) \\
\cline { 2 - 3 } liver & 0.33 & \pm 0.06 \\
bone & 9.87 & \pm 1.68 \\
Muscle & 0.14 & \pm 0.03 \\
lung & 0.11 & \pm 0.04 \\
Uterus & 21.86 & \pm 0.70 \\
ovaries & 0.28 & \pm 0.06 \\
Kidney & 0.61 & \pm 0.08 \\
spleen & 1.47 & \pm 0.24 \\
heart & 8.86 & \pm 0.75 \\
Uterus/Muscle & 0.37 & \pm 0.09 \\
Uterus/blood & 3.02 & \pm 0.86 \\
Ovaries/Muscle & 0.89 & \pm 0.27 \\
Ovaries/blood & 6.11 & \pm 0.32 \\
\hline
\end{tabular}

*2 $\mathrm{h}$ block indicates co-administration of $15 \mu \mathrm{g}$ estradiol.

To determine whether the uptake was mediated by a high affinity, limited-capacity system, a blocking study was carried out by co-injection of $80 \mu \mathrm{Ci}$ of 2 together with $18 \mu \mathrm{g} / \mathrm{g}$ estradiol to fully occupy the ER sites. The results are shown in Table 2. Uptake in ER-rich target tissues (uterus and ovaries) was reduced to $0.11 \pm 0.01$ and $0.24 \pm 0.01$, respectively. This result indicates that the uptake of $\mathbf{2}$ in the ovaries is mediated by binding to ER. No obvious differences in activity levels were observed in blood, liver, lung and spleen between blocked and nonblocked animals.

Table 3. Tissue biodistribution of compound $\mathbf{2}$ and $\mathbf{4}$ in mature female rats percent injected dose/g of tissue \pm s.d (\%ID/g of tissue).

\begin{tabular}{lcccrr}
\hline & \multicolumn{3}{c}{ Compound 2 } & \multicolumn{3}{c}{$4^{*}$} \\
\cline { 2 - 6 } & \multicolumn{2}{c}{ Ovaries } & Uterus & Ovaries & \multicolumn{1}{c}{ Uterus } \\
\cline { 2 - 6 } 15 min & $0.199 \pm 0.002$ & $0.197 \pm 0.04$ & $1.76 \pm 0.10$ & $0.44 \pm 0.15$ \\
$1 \mathrm{~h}$ & $0.27 \pm 0.060$ & $0.236 \pm 0.14$ & $0.42 \pm 0.03$ & $0.2 \pm 0.05$ \\
$2 \mathrm{~h}$ & $0.61 \pm 0.070$ & $0.283 \pm 0.05$ & $0.45 \pm 0.08$ & $0.2 \pm 0.02$ \\
$3 \mathrm{~h}$ & $0.56 \pm 0.013$ & $0.17 \pm 0.01$ & $0.13 \pm 0.01$ & $0.07 \pm 0.02$ \\
$6 \mathrm{~h}$ & $0.183 \pm 0.01$ & $0.01 \pm 0.010$ & $0.12 \pm 0.02$ & $0.04 \pm 0.01$ \\
$18 \mathrm{~h}$ & $0.021 \pm 0.000$ & $0.045 \pm 0.04$ & $0.06 \pm 0.01$ & $0.04 \pm 0.01$ \\
\hline
\end{tabular}


* Values from ref [39], [45].

Table 3 shows the biodistribution of compound $\mathbf{2}$ and $\mathbf{4}$ in mature female rats. A compared to $\mathbf{4 , 2}$ attains a maximum uptake at $2 \mathrm{~h}$ while the uptake of $\mathbf{4}$ starts to decrease from 15 min. The uptakes of 2 by ovaries and by uterus are similar, while the uptake of 4 by ovaries is much higher than that by uterus.

(a)

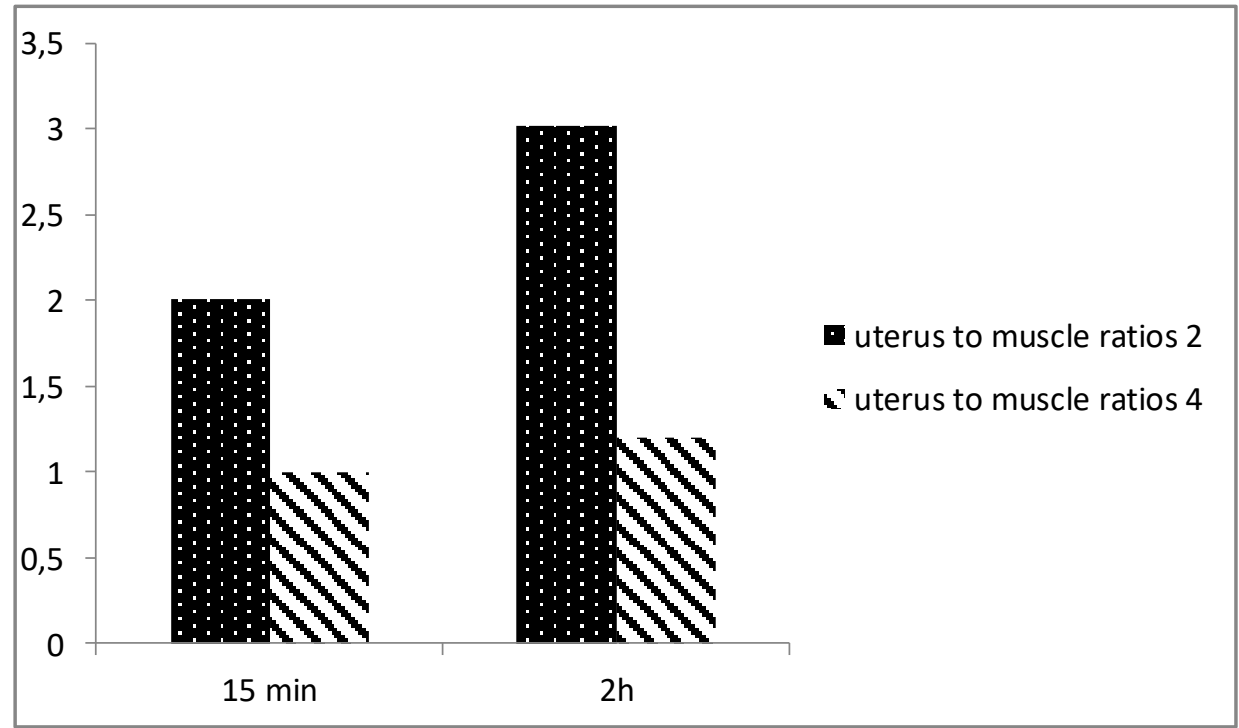

(b)

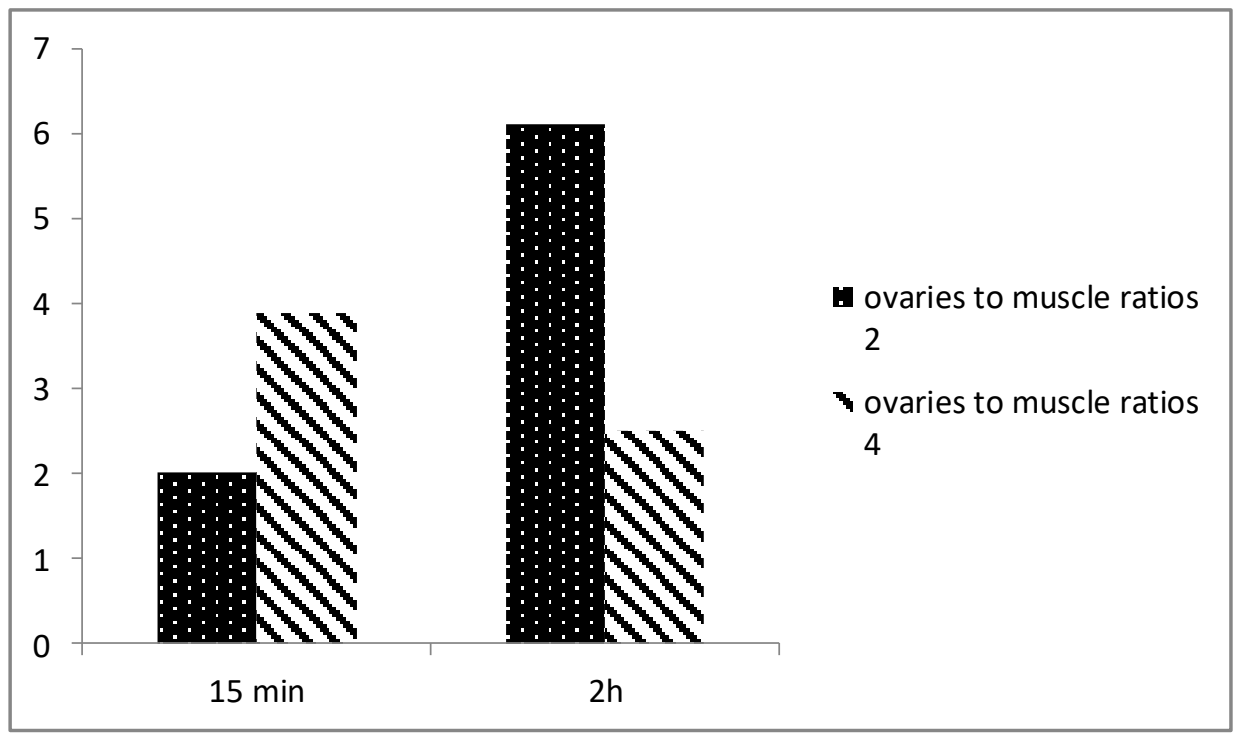


Figure 4. Uterus to muscle ratios (a) and ovaries-to-muscle ratios (b) determined by tissue biodistribution at $2 \mathrm{~h}$ post injection of compound $\mathbf{2}$ and 4 [45] respectively.

Figure 4 shows uterus to muscle ratios and ovaries to muscle ratios of 2 and $\mathbf{4}$. 4 has higher uterus to muscle ratios than that of $\mathbf{3}$. For ovaries, $\mathbf{4}$ still has better ratio value than $\mathbf{2}$ at $1 \mathrm{~h}$ but lower at $15 \mathrm{~min}$. The difference between the uptake of $\mathbf{2}$ and 4 may be due to the fact that 4 has good affinity for ER in ER rich tissue (uterus and ovaries) [39].

\section{Conclusion}

We have developed suitable conditions for the synthesis of ${ }^{99 \mathrm{~m}} \mathrm{Tc}$ compound 2 . It was obtained in good yields (90\%). Tissue distribution showed a significant selective uptake by the ovaries and a low level of activity in muscle. The fact that the ovaries/muscle uptake ratio shows a significant reduction when the receptor is blocked by co-injection of large excess of estradiol means that this uptake is ER mediated. Further studies, involving the metabolic stability of compound $\mathbf{2}$ in in vivo tumor model experiments, are currently underway.

\section{Acknowledgements.}

We thank the Ministère de l'Enseignement Supérieur et de la Recherche de Tunisie, the Centre National des Sciences et Technologies Nucléaires de Tunisie for financial support.

\section{References}

[1] D. Xu, R. Zhuang, L. You, Z. Guo, X. Wang, C. Peng, D. Zhang, P. Zhang, H. Wu, W. Pan, X. Zhang, 18F-labeled estradiol derivative for targeting estrogen receptorexpressing breast cancer, Nucl. Med. Biol. 59 (2018) 48-55.

[2] A. M. Fowler, A. S. Clark, J. A. Katzenellenbogen, H. M. Linden, F. Dehdashti, Imaging Diagnostic and Therapeutic Targets: Steroid Receptors in Breast Cancer., J Nucl Med. 
57 (2016) 75S-80S.

[3] J. M. Dixon, Exemestane and aromatase inhibitors in the management of advanced breast cancer, Expert. Opin. Pharmacother. 5 2004) 307-316.

[4] E. P. Winer, C. Hudis, H. J. Burstein, A. C. Wolff, K. I. Pritchard, J. N. Ingle, R. T. Chlebowski, R. Gelber, S. B. Edge, J. Gralow, M. A. Cobleigh, E. P. Mamounas, L. J. Goldestein, T. J. Whelan, T. J. Powles, J. Bryant, C. Prkins, J. Perotti, S. Braun, A. S. Langer, G. P. Browman, M. R. Somerfield, American Society of Clinical Oncology technology assessment on the use of aromatase inhibitors as adjuvant therapy for postmenopausal women with hormone receptor-positive breast cancer: status report 2004 , J. Clin. Oncol. 23 (2005) 619-629.

[5] F. Dehdashti, F. L. Flanagan, J. E. Mortimer, J. A. Katzenellenbogen, M. J. Welch, B. A. Siegel, Positron emission tomographic assessment of "metabolic flare" to predict response of metabolic breast cancer to antiestrogen therapy, Eur J Nucl Med. 26 (1999) $51-56$.

[6] M. C. Oliveira, C. Neto, G. Ribeiro Morais, T. Thiemann, Steroid Receptor Ligands for Breast Cancer Targeting: An Insight into Their Potential Role As Pet Imaging Agents, Curr Med Chem. 20 (2013) 1.

[7] J. L. Lim, L. Zheng, M. S. Berridge, T. J. Tewson, t, Nucl Med Biol. 23 (1996) 911-5.

[8] H. F. VanBrocklin, K. E. Carlson, J. A. Katzenellenbogen, M. J. Welch, 16 beta([18F]fluoro)estrogens: systematic investigation of a new series of fluorine-18-labeled estrogens as potential imaging agents for estrogen-receptor-positive breast tumors, J Med Chem. 36 (1993) 1619-29.

[9] M. Gaiane, M. D. Rauch, E. Beatriz, Magn Reson Imaging Clin N Am, 26 (2018) 273280.

[10] G. B. Saha, Fundamentals of Nuclear Pharmacy, Springer, New York. (2010).

[11] A. L. B. de Barros, S. F. Andrade, J. D. S. Filho, V. N. Cardoso, R. J. Alves, Radiolabeling of low molecular weight D-galactose-basedglycodendrimer with technetium-99 m and biodistribution studies, J. Radioanal. Nucl. Chem. 298 (2013) $605-609$.

[12] L. O. F. Monteiro., R. S. Fernandes, L. C. Castro, V. N. Cardoso, M. C. Oliveira, D. M. Townsend, A. Ferretti, D. Rubello, E. A. Leite, A. L. B. de Barros, Technetium-99m radiolabeled paclitaxel as an imaging probe for breast cancer in vivo, Biomed. Pharmacother. 89 2017) 146-151. 
[13] F. L. Kong, Y. Zhang, D. P. Young, D. F. Yu, D. J. Yang, Development of (99m)Tc-ECtyrosine for early detection of breast cancer tumor response to the anticancer drug melphalan, Acad. Radiol. 20 (2012)41-51.

[14] L. Quental, P. Raposinho, F. Mendes, I. Santos, C. Navarro-Ranninger, A. AlvarezValdes, H. Huang, H. Chao, R. Rubbiani, G. Gasser, A. G. Quiroga, A. Paulo, Combining imaging and anticancer properties with new heterobimetallic $\mathrm{Pt}(\mathrm{II}) / \mathrm{M}(\mathrm{I})$ (M $=$ Re, 99mTc) complexes, Dalton Trans. 46 (2017) 14423-144702.

[15] J. Beauregard, E. Turcotte, F. Bénard, Steroid receptor imaging in breast cancer, PET Clin North Am. 1 (2006) 51-70.

[16] S. D. Jonson, T. A. Bonasera, F. Dehdashti, M. E. Cristel, J. A. Katzenellenbogen, M. J. Welch,t, Nucl. Med. Biol. 26 (1999) 123-130.

[17] J. A. Katzenellenbogen, K. D. McElvany, S. G. Senderoff, K. E. Carlson, S. W. Landvatter, M. J. Welch, 16 alpha-[77Br]bromo-11 beta-methoxyestradiol-17 beta: a gamma-emitting estrogen imaging agent with high uptake and retention by target organs, J. Nucl. Med. 23 (1982) 411-9.

[18] S. W. Landvatter, J. A. Katzenellenbogen, K. D. McElvany, M. J. Welch, (2R*,3S*)-1[125I]Iodo-2,3-bis(4-hydroxyphenyl)pentane ([125I]iodonorhexestrol) and (2R*,3S*)1-[77Br]Bromo-2,3-bis(4-hydroxyphenyl)pentane ([77Br]bromonorhexestrol), two gamma-emitting estrogens that show receptor-mediated uptake by target tissues in vivo, J. Med. Chem. 25 (1982) 1307-12.

[19] K. D. McElvany, J. A. Katzenellenbogen, K. E. Shafer, B. A. Siegel, S. G. Senderoff, M. J. Welch, 16 alpha-[77Br]bromoestradiol: dosimetry and preliminary clinical studies. , J. Nucl. Med. 23 (1982) 425-30.

[20] M. G. Pomper, H. Van Brocklin, A. M. Thieme, R. D. Thomas, K. E. Kiesewetter, K. E.

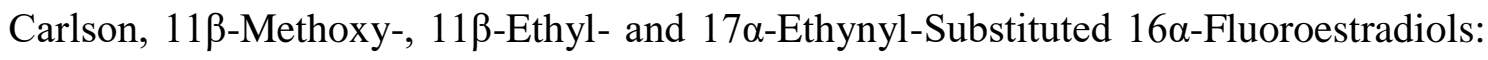
Receptor-Based Imaging Agents with Enhanced Uptake Efficiency and Selectivity, J. Med. Chem. 33 (1990) 3143- 55.

[21] Y. Seimbille, F. Benard, J. E. van Lier, Synthesis of 16 $\alpha$-fluoro ICI 182,780 derivatives:powerful antiestrogens to image estrogen receptor densities in breast cancer by positron emission tomography, J. Chem. Soc. Perkin Trans. 20 (2002) 2275-81.

[22] H. F. Van Brocklin, K. E. Carlson, J. A. Katzenellenbogen, M. J. Welch, 16.beta.([18F]Fluoro)estrogens: systematic investigation of a new series of fluorine-18-labeled estrogens as potential imaging agents for estrogen-receptor-positive breast tumors, J. 
Med. Chem. 36 (1993) 1619-1629.

[23] M. C. Oliveira, C. Neto, G. Ribeiro Morais, T. Thiemann, Steroid receptor ligands for breast cancer targeting: an insight into their potential role as PET imaging agents, Curr Med Chem. 20 (2013) 222-245.

[24] Y. Seimbille, J. Rousseau, F. Bénard, C. Morin, H. Ali, G. Avvakumov, and al, 18Flabeled difluoroestradiols: preparation and preclinical evaluation as estrogen receptorbinding radiopharmaceuticals, Steroids.67 (2002) 765-75.

[25] M. Paquette, S. Phoenix, R. Ouellet, R. Langlois, J. E. Van Lier, E. E. Turcotte, and al, Assessment of the novel estrogen receptor PET tracer 4-fluoro-11 $\beta$-methoxy-16 $\alpha$ [(18)F]fluoroestradiol (4FMFES) by PET imaging in a breast cancer murine model, Mol Imaging Biol. 15 (2013) 625-32.

[26] S. Top, J. Tang, A. D. Carrez, C. Provot, G. Jaouen, Ferrocenyl hydroxytamoxifen: a prototype for a new range of oestradiol receptor site-directed cytotoxics, Chem. Commun. (1996) 955.

[27] G. Jaouen, S. Top, A. Vessières, G. Leclercq, J. Quivy, L. Jin, and A. Croisy, The first organometallic antioestrogens and their antiproliferative effects, C. R. Acad. Sci. Paris Série IIc (2000) 89-93.

[28] S. Top, A. Vessières, G. Leclercq, J. Quivy, J. Tang, J. Vaissermann, M. Huché, and G. Jaouen, Synthesis, biochemical properties and molecular modelling studies of organometallic specific estrogen receptor modulators (SERMs), the ferrocifens and hydroxyferrocifens: evidence for an antiproliferative effect of hydroxyferrocifens on both hormone-dependent and hormone-independent breast cancer cell lines, Chem. Eur. J. 9 (2003) 5223-5236.

[29] A. Nguyen, S. Top, P. Pigeon, A. Vessières, E. A. Hillard, M.-A. Plamont, M. Huché, C. Rigamonti, G. Jaouen, Synthesis and structure-activity relationships of ferrocenyl tamoxifen derivatives with modified side chains, Chem. Eur. J. 15 (2009) 684-696

[30] M. Wenzel and C. Klinge, Tc-99m markierte Östradiol-derivate synthese, organverteilung und tumor-affinität, J. Labelled Comp. Radiopharm. 34 (1994) 981987.

[31] T. W. Spradau, W. B. Edwards, C. J. Anderson, M. J. Welch, and J. A. Katzenellenbogen, Synthesis and biological evaluation of Tc-99mcyclopentadienyltricarbonyltechnetium-labeled octreotide, Nucl. Med. Biol. 26 (1999) $1-7$. 
[32] F. Minutolo, and J. A. Katzenellenbogen, A Convenient Three-Component Synthesis of Substituted Cyclopentadienyl Tricarbonyl Rhenium Complexes, Organometallics. 18 (1999) 2519-2530.

[33] R. Alberto, K. Ortner, N. Wheatley, R. Schibli, A.P. Schubiger, Synthesis and Properties of Boranocarbonate: A Convenient in Situ CO Source for the Aqueous Preparation of [99mTc $\left.\left(\mathrm{OH}_{2}\right) 3(\mathrm{CO})_{3}\right]+$, J. Am. Chem. Soc. 123 (2001) 3135-3136.

[34] J. Wald, R. Alberto, K. Ortner, L. Candreia, Aqueous One-Pot Synthesis of Derivatized Cyclopentadienyl-Tricarbonyl Complexes of 99mTc with an In Situ CO Source: Application to a Serotonergic Receptor Ligand, Angew. Chem. Int. Ed. 40 (2001) 30623066.

[35] R. Alberto, New organometallic Technetium Complexes for radiopharmaceutical imaging, Top Curr. Chem. 252 (2005) 1-44.

[36] D. Can, B. Spingler, P. Schmutz, F. Mendes, P. Raposinho, C. Fernandes, F. Carta, A. Innocenti, I. Santos, C. T. Supuran, and R. Alberto, [(Cp-R)M(CO)3] (M=Re or 99mTc) Arylsulfonamide, arylsulfamide, and arylsulfamate conjugates for selective targeting of human carbonic anhydrase IX, Angew. Chem. Int. Ed. 51 (2012) 3354-3357.

[37] A. Nguyen, PhD thesis, 2007, Univerité P. et M. Curie, France.

[38] S. Masi, S. Top, L. Boubekeur, G. Jaouen, S. Mundwiler, B. Spingler, and R. Alberto, Direct synthesis of tricarbonyl(cyclopentadienyl)rhenium and tricarbonyl(cyclopentadienyl)technetium units from ferrocenyl moieties - Preparation of 17 alpha-ethynylestradiol derivatives bearing a tricarbonyl(cyclopentadienyl)technetium group, Eur. J. Inorg. Chem. (2004) 2013-2017.

[39] T. Dallagi, M. Saidi, A. Vessières, M. Huché, G. Jaouen, S. Top, Synthesis and antiproliferative evaluation of ferrocenyl and cymantrenyl triaryl butene on breast cancer cells. Biodistribution study of the corresponding technetium-99m tamoxifen conjugate,J. Organomet. Chem. 734 (2013) 69-77.

[40] T. Dallagi, M. Saidi, G. Jaouen, S. Top, Synthesis and antiproliferative activity of $(Z+E)-1-[4-(2-(c y c l o p e n t a d i e n y l t r i c a r b o n y l m a n g a n e s e)-2-o x o-e t h o x y) p h e n y l]-1,2-d i(p$ -hydroxyphenyl)-but-1-ene against breast cancer cells, Appl. Organometal. Chem. 27 (2013) 28-35.

[41] R.S. Fernandes, J.O. Silva, S.V.A. Lopes, S. Chondrogiannis, D. Rubello, V.N. Cardoso, Technetium-99 m radiolabeled paclitaxel as an imaging probe for breast cancer in vivo, Biomed pharmacother. 37 (2016) 307-312. 
[42] C. S. Cutler, H.M. Hennkens, N. Sisay, S. Huclier-Markai, S. S. Jurisson, Radiometals for combined imaging and therapy, Chem. Rev. 113 (2013) 858-883.

[43] USP 34. The United States Pharmacopoeia National Formulary. Rockville: United States Pharmacopoeial Convention Inc.; 2012.

[44] E. E. Parent, C. Jenks, T. Sharp, M. J. Welch, and J. A. Katzenellenbogen, Synthesis and biological evaluation of a nonsteroidal bromine-76-labeled androgen receptor ligand 3[76Br] bromo-hydroxyflutamide, Nucl. Med. Biol. 33 (2006) 705-713

[45] T. Dallagi, PhD thesis, 2010, Univerité P. et M. Curie, France. 
Table 1. Tissue biodistribution of compound 2 in mature female rats (\% ID/g of tissue)

\begin{tabular}{|c|c|c|c|c|c|c|c|c|c|c|c|c|c|c|}
\hline & Percer & t inject & gram & ES.D. (n & & & & & & & & & & \\
\hline & $15 \mathrm{~min}$ & & $1 \mathrm{~h}$ & & $2 \mathrm{~h}$ & & $3 \mathrm{~h}$ & & $6 \mathrm{~h}$ & & $18 \mathrm{~h}$ & & $24 \mathrm{~h}$ & \\
\hline Blood & 0.46 & \pm 0.05 & 0.33 & \pm 0.11 & 0.39 & \pm 0.05 & 0.31 & \pm 0.01 & 0.13 & \pm 0.00 & 0.03 & \pm 0.01 & 0.02 & \pm 0.02 \\
\hline Liver & 2.43 & \pm 0.64 & 7.78 & \pm 0.63 & 9.87 & \pm 1.68 & 10.52 & \pm 0.89 & 1.89 & \pm 0.720 & 0.24 & \pm 0.04 & 0.580 & \pm 0.07 \\
\hline bone & 0.23 & \pm 0.09 & 0.12 & \pm 0.03 & 0.14 & \pm 0.031 & 0.20 & \pm 0.05 & 0.06 & \pm 0.015 & 0.016 & \pm 0.0 & 0.022 & \pm 0.00 \\
\hline Muscle & 0.09 & \pm 0.00 & 0.12 & \pm 0.02 & 0.11 & \pm 0.04 & 0.17 & \pm 0.06 & 0.034 & \pm 0.003 & 0.006 & \pm 0.00 & 0.007 & \pm 0.00 \\
\hline Lung & 7.69 & \pm 0.89 & 6.62 & \pm 0.25 & 21.86 & \pm 0.70 & 24.81 & \pm 0.60 & 6.20 & \pm 0.943 & 1.067 & \pm 0.30 & 1.143 & \pm 0.022 \\
\hline Uterus & 0.19 & \pm 0.04 & 0.23 & \pm 0.14 & 0.28 & \pm 0.05 & 0.17 & \pm 0.01 & 0.1 & \pm 0.01 & 0.045 & \pm 0.04 & 0.033 & \pm 0.04 \\
\hline Ovaries & 0.19 & \pm 0.00 & 0.27 & \pm 0.06 & 0.61 & \pm 0.07 & 0.56 & \pm 0.013 & 0.18 & \pm 0.01 & 0.021 & \pm 0.00 & 0.036 & \pm 0.02 \\
\hline kidney & 0.43 & \pm 0.02 & 0.47 & \pm 0.18 & 1.47 & \pm 0.023 & 2.03 & \pm 0.045 & 1.13 & \pm 0.038 & 0.440 & \pm 0.016 & 0.340 & \pm 0.016 \\
\hline Spleen & 1.32 & \pm 0.23 & 6.49 & \pm 0.43 & 8.85 & \pm 0.75 & 4.84 & \pm 0.09 & 0.28 & \pm 0.09 & 0.044 & \pm 0.01 & 0.081 & \pm 0.01 \\
\hline Heart & 0.22 & \pm 0.02 & 0.21 & \pm 0.06 & 0.36 & \pm 0.08 & 0.3 & \pm 0.08 & 0.15 & \pm 0.01 & 0.025 & \pm 0.00 & 0.031 & \pm 0.01 \\
\hline
\end{tabular}




\section{Captions}

Chart 1. Ferrocenyl, manganese and ${ }^{99 \mathrm{~m}} \mathrm{Tc}$ derivatives.

Chart 2 Cyclopentadienyltricarbonyltechnetium-99m 4

Scheme 1. synthesis of cyclopentadienyltricarbonyltechnetium compound 2

Figure 1. (a) UV-HPLC (254 nm) chromatogram of $\mathbf{3}$ and (b) Radio-HPLC chromatogram of 2.

Figure 2. In vitro stability of $\mathbf{2}$ as a function of time in the presence of saline solution (Series 1), at room temperature, or rat plasma (Series 2), at $37^{\circ} \mathrm{C}$.

Figure 3. In vivo disappearance of compound $\mathbf{2}$ in mature female rats.

Figure 4. Uterus to muscle ratios (a) and ovaries-to-muscle ratios (b) determined by tissue biodistribution at $2 \mathrm{~h}$ post injection of compound 2 and 4 [45] respectively.

Table 1. Tissue biodistribution of compound 2 in mature female rats (\%ID/g of tissue)

Table 2. Tissue biodistribution of $\mathbf{2}$ in mature female rats: blocking study.

Table 3. Tissue biodistribution of compound $\mathbf{2}$ and $\mathbf{4}$ in mature female rats percent injected dose/g of tissue \pm s.d (\%ID/g of tissue).

\section{Highlights:}

Ferrocenyl butene compound was prepared for its use as a precursor of Tc analog.

Using metal exchange reaction, ferrocenyl compound was transformed to ${ }^{99 \mathrm{~m}} \mathrm{Tc}$ analog in $90 \%$ yield.

Biodistribution of the Tc compound was studied in rats.

Uptake by ovaries was mediated by hormone receptors. 